\title{
O FUNDO fALsO dA SUBJETIVIDADE
}

\author{
JÓIAS DE FAMÍLIA, \\ de Zulmira Ribeiro Tavares. São Paulo: Companhia das Letras, 2007.
}

ANA PAUla PACHECO

“(...) porque assuntos de jóias por menos que pareçam se misturam muito aos da existência, merecendo ser examinados de diferentes ângulos"

Jóias de família, de Zulmira Ribeiro Tavares, acaba de ser republicado por uma de nossas maiores editoras. Veio a público pela primeira vez em 1990 e, após uma seqüência de quatro edições, caiu no limbo dos "difíceis de achar". Dir-se-ia, com um pouco de malícia, que para o mercado brasileiro teve relativamente boa sorte. No contexto, que confunde o contemporâneo com a disputa pelo mais novo, o relançamento é oportunidade para repensar o interesse de um livro cuja úl tima edição já data de doze anos, e de uma obra que teve início há trinta e poucos, com o volume Termos de comparação (1974). Ainda que a proposta aparente alguma extravagância, não me parece exagerado testar a atualidade do contemporâneo, seja porque o mercado reserva à literatura estranhas metamorfoses no fim do dia, seja porque as ideologias veiculadas diariamente pela indústria cultural transformam porvezes o sentido das formas literárias, agindo retroativamente sobre elas, ao rotinizá-las. Nessa direção nunca é demais lembrar que os procedimentos literários têm pressupostos extraliterários, e que o curso da história pode modificar o sentido original desses procedimentos artísticos.

O primeiro livro de Zulmira, dividido em três sessões, ensaio, conto e poesia, indicava um caminho em que seria significativo o trânsito por diferentes gêneros, figurando lado a lado criação e reflexões sobre ficção e conhecimento, algo pouco comum entre nós. Posteriormente, no romance $O$ nome do bispo (1985), o que estava separado passa a integrar uma estrutura: a linguagem ensaística do narrador marca a tentativa de apreender a realidade narrada, um modo da invenção quando o real tornou-se, também para esta, mais e mais inapreensível. Talvez valha aqui uma nota sobre o termo "ensaístico", aplicado 
à criação literária. Roberto Schwarz o empregou (definindo, entre outros, o estilo de $O$ nome do bispo ${ }^{1}$ ) num sentido hoje corrente para a crítica brasileira, a saber, o de uma ficção que mostra (por intermédio da figura do narrador) uma atitude analítica diante da realidade representada, à maneira do que o ensaio filosófico, na tradição de Montaigne, fazia perante a matéria da vida real.É claro que a analogia supõe diferenças, pois em Montaigne a reflexão é constitutiva da formação de uma subjetividade burguesa; na Europa, àquela altura, um ideário possível. Os livros de Zulmira, brasileiros e de outro tempo, tiram conseqüências estéticas da atenção às particularidades históricas: na sua ficção, o "ensaísmo" do narradoré virado pelo avesso, tornando-se por assim dizer exame da derrocada de indivíduos burgueses e da renitência com que as prerrogativas de classe se mantêm. Além disso, trata-se de uma postura do narrador, cuja máscara é a da análise, diretamente exposta. O recurso técnico pode ter rendimento formal: se a autoconsciência do lugar da arte faz ainda parte da ordem do dia (no caso, estamos diante de um "fingimento" que toma distância de si mesmo), mas a repetição da metalinguagem transforma-a em ludismo, há uma dimensão estruturante nesse expediente do narrador. Adianto que a linguagem ensaística, em tom de gracejo, traz no caso alguma simetria (inversa?) com a pose da elite que tem em mira (e para a qual a racionalização das injustiças não é o oposto do jogo nem do cinismo).

Conjugado à linguagem ensaística, outra marca da narrativa de Zulmira é o humor constante. Reflexão e humor geram uma combinação que indaga as aparências do mundo e delas desconfia. Assim, as experiências das personagens - via de regra pertencentes à burguesia paulistana, quatrocentona e decadente - e a própria arte ficam sob suspeita, e constantemente rebaixadas.

Vale lembrar que esse enfoque não é o mais freqüente na narrativa brasileira contemporânea, que tem se voltado sobretudo à representação dos excluídos de nossa sociedade, dando corpo ao que se convencionou chamar de literatura marginal (pelo assunto, pela posição social do escritor marginalizado, e mais especificamente pelo próprio lugar social dessa escrita, por vezes situado nas condições lastimáveis de nossas penitenciárias, onde alguns detentos vêm compondo seus relatos). Nessa direção os livros de Zulmira - particularmente Onome do bispo e Jóias de família - aproximam-se, no quadro da produção contemporânea, da posição ocupada por Três mulheres de três pppês, de Paulo Emílio Salles Gomes quando de sua publicação em 1977. Naquela época em que a alegorização do Brasil sob a ditadura dava a tônica da representação, buscando denunciar a violência institucionalizada, o livro de Paulo Emílio trazia uma virada: em tonalidade humorística, tematizando as mazelas das relações amorosas na alta roda da sociedade paulistana, os qüiproquós da vida privada e o fundo falso da iden-

[1] Cf.Schwarz, Roberto. "O nome do bispo: um romance paulista”. In Que horas são? São Paulo, Companhia das Letras, 1997.2 ${ }^{\mathrm{a}}$ reimpressão.p. 67-70. 
[2] Cf. Schwarz, Roberto. "Sobre as Três mulheres de três pppês". In O pai de família e outros estudos. São Paulo, Paz e Terra, 1992. 2 a ed. p. 127-147.
[3] Quem observou tal peculiaridade foi Modesto Carone, em "A fábula do revés e o reverso da fábula", republicado este ano na reedição de Três mulheres de três pppês (São Paulo, Cosac \& Naify, 2007). tidade do protagonista Pollydoro ganhavam a cena. Nas três partes que compõem este livro, a vida do personagem-narrador é sempre reperspectivada por revelações que colocam em causa o sentido dos seus amores, mas não só: sua própria voz é desmentida a todo momento e passa a ser testemunho da possibilidade de fazer e desfazer do real, a seu bel prazer - como se também a "realidade do real" fosse uma prerrogativa de classe. O expediente camaleônico do narrador-personagem (sempre o mesmo Pollydoro e sempre outro), capaz de sacudir a poeira a cada nova queda, ultrapassa no livro a dimensão meramente humorística, embasada nas sucessivas peripécias que dão a tônica do entretenimento (também presente ali), e põe à vista os privilégios de uma classe que faz da vida e da identidade um constante jogo. Aliás, como parte do jogo não está ausente o momento da ditadura sob a qual o país se encontrava (notou-o Roberto Schwarz num ensaio de 1978, no qual me baseio ${ }^{2}$ ). Tal momento éincorporado como um fato que a personagem não desconhece, e usa a seu favor. Mas a situação de violência explícita não ocupa o centro e surge justamente como algo subsumido à premência da vida privada (as paixões, os desmandos, as desilusões de Pollydoro, a quem não importa o que não seja sua própria obra mal composta, seus amores, sua vaidade pessoal).Istoé, a violência daqueles anos aparece sob a ótica de uma classe que teve parte nela, ao mesmo tempo em que agia como se não tivesse nada com isso. Nesse sentido, Três mulheres de trêspppês dá testemunho de comportamentos, ou formas sociais, típicos da elite brasileira. Isso está estruturado num narrador que se oferece como palhaço ${ }^{3}$, escancarando o ridículo, a desfaçatez e também a má consciência dessa elite, que Paulo Emílio quis pôr à mostra, como "traidor de classe" que foi. Em paralelo, por assim dizer, às encenações de Pollydoro, o próprio livro apresenta uma caricatura do que seja a ficção, investindo em procedimentos de vaudeville (também identificados por Schwarz). Estes, pelo exagero, levam a desacreditar a invenção do real, a sua literarização por parte desse narrador, ao passo que revelam aquele momento histórico sob o olhar da classe alta.

Algo dessa técnica do exagero como procedimento crítico, regado a humor, está presente em Onome do bispo e em Jóias de família. Também neles há um modo imprevisto de lidar com o desvendamento de uma subjetividade cuja origem social vem bem assinalada. O primeiro, mais próximo da época da publicação de Três mulheres, trata o assunto premente da violência sob a ditadura militar de um modo, na aparência, lateral, ou, na metáfora corpórea em que seenquistam as analogias no livro, "recôndito" (Heládio Marcondes Pompeu, o protagonista, sofre de um "mal ridículo": "uma pequena infâmia que se desenvolveu sorrateiramente, à margem de sua consciência, nos cômodos inferiores de seu corpo", uma fissura no ânus. É no hospital que o contexto da 
vida do personagem e do país será passado em revista).Já no limiar dos anos 90, Jóias de família afasta-se do quadro da ficção brutalista e da ficção marginal mais significativa, representando o todo social a partir de outro ponto de vista. A novela faz das encenações da elite paulistana sua matéria, elegendo centralmente o foco de uma mulher que aprendeu a sevaler das falsas aparências, vigentes em seu meio. Avizinha-se, em linha de continuidade, também da prosa machadiana, de um ângulo relativamente novo, que é o da mulher rica, ou de família rica, agarrada às ruínas do antigo patrimônio.

A identidade de Maria Bráulia Munhoz é desvendada ao leitor por meio de uma intrincada trama envolvendo falseamento e autenticidade de um anel de noivado, que ocupa o centro do enredo.A réplica da gema valiosíssima guardada no cofre esconde um casamento de aparências e duplica outra gema igualmente falsa, a "original", no fundo a mesma - a duplicação é mágica feita pelo noivo de extração social mais baixa, para impressionar a família da noiva. Acompanhando sucessivas peripécias, seguimos as perplexidades da moça, que entretanto aprende com o tempo a se adaptar muito bem às circunstâncias. Relembro algumas das peripécias centrais, para que se tenha em mente o andamento movimentado do enredo: perda da réplica, descoberta de que esta é tão perfeita que fez Bráulia confundir-se e perder, na verdade, a original; percepção de que seu marido, o juiz Munhoz, é amante do secretário particular; paixão entre o novo joalheiro, levado à casa pelo marido, e Maria Bráulia; desvendamento do segredo das jóias pelo joalheiro, que presenteia a matriarca com um (finalmente) verdadeiro rubi; anos depois, interesse do sobrinho pelas jóias da tia; reprodução, por parte dela, do jogo de aparências (novamente a trama das pedras verdadeiras e falsas) para livrar-se do interesseiro.

A movimentação assemelha-se à da narrativa de entretenimento, embasada em muitas peripécias e algum suspense, mas ganha força por articular-se à revelação do modo de ser de uma classe. Em alguma medida, a leveza, "para consumo", da narrativa policialesca torna-se uma maneira adequada de penetrar num círculo de relações em que quase tudo é aparência, e a aparência, uma verdade social. A metáfora que serve de eixo ao livro é, a propósito, a de um cisne de Murano sobre um lago, enfeite de mesa na sala de jantar. $\mathrm{O}$ lago tem a profundidade enganosa do espelho e, nele, Narciso não se afoga.

O desmascaramento acontece e traz algum fundo autêntico (Maria Bráulia passa a amar Marcel, o joalheiro, o juiz Munhoz será até o fim da vida companheiro de seu secretário), mas converge afinal com a superfície das conveniências sociais (o casamento deve permanecer,e a mentira é seu acordo tácito; tia Brau deve fingir não perceber os móveis secretos da dedicação do sobrinho). É interessante, nesse sentido, que procedimentos da narrativa policialesca - sobretudo sus- 
pense e desmascaramentos - sejam adequados mesmo à interrogação da identidade.Acompanhando o ângulo de Maria Brau, que se cola ao proscênio da vida de salão, o narrador vê restarem por detrás da máscara apenas "formas apagadas, mal definidas e rugosas, como o interior pálido das ostras", das quais emerge, todavia, "um espírito muito fino, animado e alegrinho". A identidade diáfana, se comparada à da mulher que se impõe calibrada por muitas camadas de pó de arroz, não é como um teatro às escuras. Mesmo que no espelho a imagem apareça "esvaziada", Bráulia se revigora com a oportunidade de estar a sós com seu segredo, o verdadeiro rubi. A técnica do suspense tem então sentido duplo: diante do desconhecimento, queé da própria personagem (sozinha no quarto, não há rosto que venha à tona), tudo são pistas para o narrador; a investigação da subjetividade, entretanto, tem a espessura do entretenimento (afinal, quem precisa ser uno?). A ilusão de uma subjetividade formada - a um só tempo singulare versátil - funciona ideologicamente como prerrogativa de indivíduos de uma classe (com seu lado de verdade num país em que só a elite pode dizer "eu"). O teor do enunciado formal do livro de Zulmira nos devolve um retrato algo esquemático dessa dinâmica histórica ( $e$ talvez excessivamente explícito em suas metáforas), constituindo, assim, também o seu limite. (Vale observar que outras narrativas contemporâneas brasileiras, em tons diversos, valem-se de elementos do romance policial na interrogação da subjetividade, caso por exemplo de Estorvo, de Chico Buarque - mas nele, de modo significativo, a "investigação" gira em falso, coerente com um universo social em que o sujeito está próximo de um vulto).

O problema do falseamento não é só tema de Jóias de família, e nos encaminha para uma questão teórica mais ampla. Certamente esta não diz respeito a uma obra específica, mas o teatro de falseamento e verdade no livro ajuda a pensá-la em nosso contexto histórico-literário. Nas célebres "Reflexões sobre o romance contemporâneo", Adorno formula a questão central para a narrativa realística pós-vanguardas históricas: o realismo tradicional (aquele que imanta o leitor, fazendo crer na ilusão referencial) não poderia ser retomado, sob pena de reproduzir a aparência enganosa de um mundo intransparente. A partir das vanguardas, portanto, impõe-se a superação do realismo de fachada, e as possibilidades da representação realista passam necessariamente pela busca de novas formas. Em Jóias de família, o falseamento da realidade, posto de uma perspectiva interna (como vimos, a de uma classe que pode jogar com a realidade à sua volta), torna-se uma aposta formal astuciosa: fazer do engano marca estrutural do livro, dar representação a uma dinâmica social não só por detrás, mas na própria aparência das relações sociais e identitárias, é um dos pontos de interesse do realismo de Zulmira ao brincar com as fachadas. 
O engano diz respeito inclusive ao esvaziamento do suspense (a trama das pedras se resolve e a das identidades - quem é cada personagem para si mesma e para os outros? — vai perdendo a ênfase). Se o qüiproquó com as pedras verdadeiras/falsas seduz num primeiro momento, o enredo sofre aos poucos um efeito de esfriamento e distância, assinalado pelo foco narrativo. Este, sem prejuízo das tiradas de ensaísmo crítico 4 , mimetiza, enquanto acompanha o ângulo de várias personagens, uma solidariedade formal com a elite. Embora estejamos diante de narrador impessoal, ele se vale de regalias com relação à narrativa afins às de classe: dentre elas, a técnica de transitar por diversos assuntos e épocas das vidas narradas, assinalando o passe de mágica ao deslizarvelozmente por tudo, como o onipresente cisne de Murano; ou a técnica de colocar observações agudas em tom de comédia leve, às vezes entre parênteses, como se quisesse não mais que um olhar crítico en passant. Não é, portanto, sem ironia que o narrador de $3^{\text {a }}$ pessoa acompanha as brechas pelas quais a mocinha de família, e depois a matrona já experiente, vai aprendendo a se esgueirar (do casamento de aparências, do sobrinho interesseiro, do medo que sente das empregadas) e a se reinventar.A ironia, ambiguamente, ora indica distância com relação ao mundo narrado e sua lei de cinismos, ora revela um à vontade desconcertante, guardando seu veredicto para o final.

O cinismo de classe de Maria Brau ancora-se na representação de situações que dão os fundamentos materiais das astúcias da personagem, inclusive na relação com outras classes sociais — o convívio com as empregadas valeria uma análise, sobretudo porque coloca o tema atualíssimo da bondade como máscara social do medo, da qual passa longe a intenção de e o direito à igualdade. Seu jogo é "plenamente justificável", assim como o do juiz Munhoz - "in dúbio pro reo", diz este a Bráulia antes de morrer. A sentença poderia caber na boca do narrador que os acompanha. No último capítulo, todavia, o tom de alegreto (a um só tempo crítico e algo acomodado na distância relativa ao "material" que examina) cede lugar ao riso amargo. O clima é de fim de drama, quando baixam as cortinas; "várias cabeças rolaram", diz ele, "umas fora da vida, outras nos travesseiros". A piada cínica dá lugar ao patético e tudo vai se aquietando na luz branquicenta da manhã que empresta vida apenas ao que não tem chance de existir: reencontramos a imagem do cisne, "um defuntinho de pé" no fecho da narrativa.

Voltando ao nosso ponto de partida (os procedimentos literários têm fundamentos extra-artísticos e podem ser ressignificados), vale indagar hoje a eficácia de aspectos decisivos da técnica da autora nesse livro, aqui apontados, a saber, a representação do cinismo de classe das personagens e a tonalidade irônica do narrador. Isto é, vale indagar sua força crítica num momento em que a indústria cultural os
[4] "Maria Preta é como se fosse da família. Em algumas circunstâncias isso quer dizer exatamente o que enuncia: que Maria Preta é como se fosse da família. Em outras, que Maria Preta não é como se fosse da família, uma vez que não é da família,é apenas 'como se fosse'." 
[5] Vale observar que na novela de Zulmira o foco se atém a uma elite paulistana morta, cujos espectros, sem deixarem de ser contemporâneos, já não estão no centro da cena social. rotinizou. Como sabemos, várias propagandas fazem hoje das prerrogativas de classe ("Só 35.000 reais", diz o anúncio do carro) um modo de vender, aos que têm como pagar, produtos impagáveis para a maioria da população; descartando, de maneira até então inédita, mesmo a má consciência, e expondo sem pudor seus móveis escusos. Em alguma medida, a avaliar em cada obra específica, a rotinização da ironia e do cinismo ocasionada pelo uso constante que a propaganda faz deles parece abalar seu poder de estranhamento diante do estabelecido. À revelia da vontade crítica, ironia e cinismo às vezes passam a soar como arma ingênua, desmascaramento insuficiente de uma realidade que já desmascarou a si mesma para continuar idêntica. No entanto, o contra-argumento salta à vista: o uso que os mass-media fazem deles não reduz, ainda hoje, por exemplo, o poder de revelação da obra de Machado, provavelmente porque não se trata só disso, mas da precisão com que estão representadas dinâmicas de classe e sua matéria específica5.

Nesse novo horizonte problemático, que se tornou mais ostensivo desde a primeira publicação de Jóias de família, vejo pelo menos dois aspectos que fazem este livro resistir: nele, muito embora as esferas sociais reduzam-se ao mundo doméstico, a matéria da vida privada não aparece destacada do todo social, isto é, as formas cordatas da violência estão presentes como velhos hábitos, consentidos pela sociedade em seu conjunto, ainda que sua representação seja simplificada (nesse sentido a violência no livro aparece como o inverso da espetacularização da violência); em segundo lugar, os estratagemas do foco narrativo desatam a crença numa subjetividade que se reencontrasse por meio da investigação, do mergulho na interioridade ou do desvendamento do que está por detrás das aparências. Sua dinâmica não diz respeito à "profundidade" de indivíduos e seus fundos secretos, mas à derrocada (social) da subjetividade: "um defuntinho de pé", no caso, ainda sustentado por privilégios de classe.

ANA PAUla PACHECO, professora do Departamento de Teoria Literária e Literatura Comparada da USP, é autora de Lugar do mito: narrativa e processo social nas Primeiras estórias de Guimarães Rosa (Nankin Editorial, 2006). 
ESTE NÚMERO FOI FINANCIADO PELA FUNDAÇÃO CARLOS CHAGAS 